\title{
Heterogeneity of Multiple System Atrophy: An Update
}

\author{
Kurt A. Jellinger (D)
}

check for

updates

Citation: Jellinger, K.A.

Heterogeneity of Multiple System Atrophy: An Update. Biomedicines 2022, 10, 599. https://doi.org/ 10.3390/biomedicines10030599

Academic Editor: Marc Ekker

Received: 7 February 2022

Accepted: 2 March 2022

Published: 3 March 2022

Publisher's Note: MDPI stays neutral with regard to jurisdictional claims in published maps and institutional affiliations.

Copyright: (C) 2022 by the author. Licensee MDPI, Basel, Switzerland. This article is an open access article distributed under the terms and conditions of the Creative Commons Attribution (CC BY) license (https:/ / creativecommons.org/licenses/by/ $4.0 /)$.
Institute of Clinical Neurobiology, Alberichgasse 5/13, Vienna A-1150, Austria; kurt.jellinger@univie.ac.at; Tel.: +43-1-5266534; Fax: +43-1-5266534

\begin{abstract}
Multiple system atrophy (MSA) is a fatal, rapidly progressing neurodegenerative disease of uncertain etiology, clinically characterized by various combinations of Levodopa unresponsive parkinsonism, cerebellar, autonomic and motor dysfunctions. The morphological hallmark of this $\alpha$-synucleinopathy is the deposition of aberrant $\alpha$-synuclein in both glia, mainly oligodendroglia (glial cytoplasmic inclusions /GCIs/) and neurons, associated with glioneuronal degeneration of the striatonigral, olivopontocerebellar and many other neuronal systems. Typical phenotypes are MSA with predominant parkinsonism (MSA-P) and a cerebellar variant (MSA-C) with olivocerebellar atrophy. However, MSA can present with a wider range of clinical and pathological features than previously thought. In addition to rare combined or "mixed" MSA, there is a broad spectrum of atypical MSA variants, such as those with a different age at onset and disease duration, "minimal change" or prodromal forms, MSA variants with Lewy body disease or severe hippocampal pathology, rare forms with an unusual tau pathology or spinal myoclonus, an increasing number of MSA cases with cognitive impairment/dementia, rare familial forms, and questionable conjugal MSA. These variants that do not fit into the current classification of MSA are a major challenge for the diagnosis of this unique proteinopathy. Although the clinical diagnostic accuracy and differential diagnosis of MSA have improved by using combined biomarkers, its distinction from clinically similar extrapyramidal disorders with other pathologies and etiologies may be difficult. These aspects should be taken into consideration when revising the current diagnostic criteria. This appears important given that disease-modifying treatment strategies for this hitherto incurable disorder are under investigation.
\end{abstract}

Keywords: multiple system atrophy; atypical forms; clinico-pathological variants; MSA with lewy bodies; "minimal change" MSA; MSA with hippocampal pathology; conjugal MSA

\section{Introduction}

Multiple system atrophy (MSA) is a rare and fatal adult-onset neurodegenerative disease of an uncertain etiology that has a variety of clinical and pathological variants. Belonging to the group of $\alpha$-synucleinopathies, it is a unique proteinopathy with a specific glioneuronal degeneration involving striatonigral, olivopontocerebellar (OPC), autonomic and peripheral neuronal systems [1]. MSA is clinically characterized by various combinations of Levodopa unresponsive parkinsonism, autonomic dysfunctions, and cerebellar and pyramidal signs [2,3]. Its morphological hallmark is the abnormal accumulation of aberrant fibrillary $\alpha$-synuclein $(\alpha$ Syn) in oligodendrocytes as glial cytoplasmic inclusions (GCIs) [4], as well as in select subsets of neurons [5] inducing cell dysfunction and death. The degeneration of specific neuronal pathways causes multifaceted clinical phenotypes: a parkinsonian variant (MSA-P), associated with striatonigral degeneration (SND), and a cerebellar variant (MSA-C) with olivopontocerebellar atrophy (OPCA) [2]. However, the clinical and morphological features of MSA are more widespread than previously considered and, in view of the limitations of the Unified Multiple System Atrophy Rating Scale (UMSARS), further development and validation of an impaired clinical outcome assessment is a priority for future research [6]. In addition to "mixed" MSA with a combination 
of both phenotypes, there are several clinico-pathological variants $[1,7,8]$, which will be critically reviewed here in order to improve diagnostic accuracy of this disorder that shows overlap with other extrapyramidal disorders. The underlying pathogenic mechanisms are still not well understood, but there is evidence for the notion that a "prion-like" spreading of disease-specific $\alpha$ Syn strains is involved in the pathogenic cascade $[9,10]$. Together with oxidative stress, proteasomal and mitochondrial dysfunctions, myelin dysregulation, the redistribution of the oligodendrocyte-specific protein p25 $\alpha$, neuroinflammation, impaired neurotrophic factors, and energy failure, it is involved in the complex pathogenic process finally leading to a specific multisystem degeneration in this oligodendroglio-neuronal proteinopathy [1,9,11-16] (Figure 1).

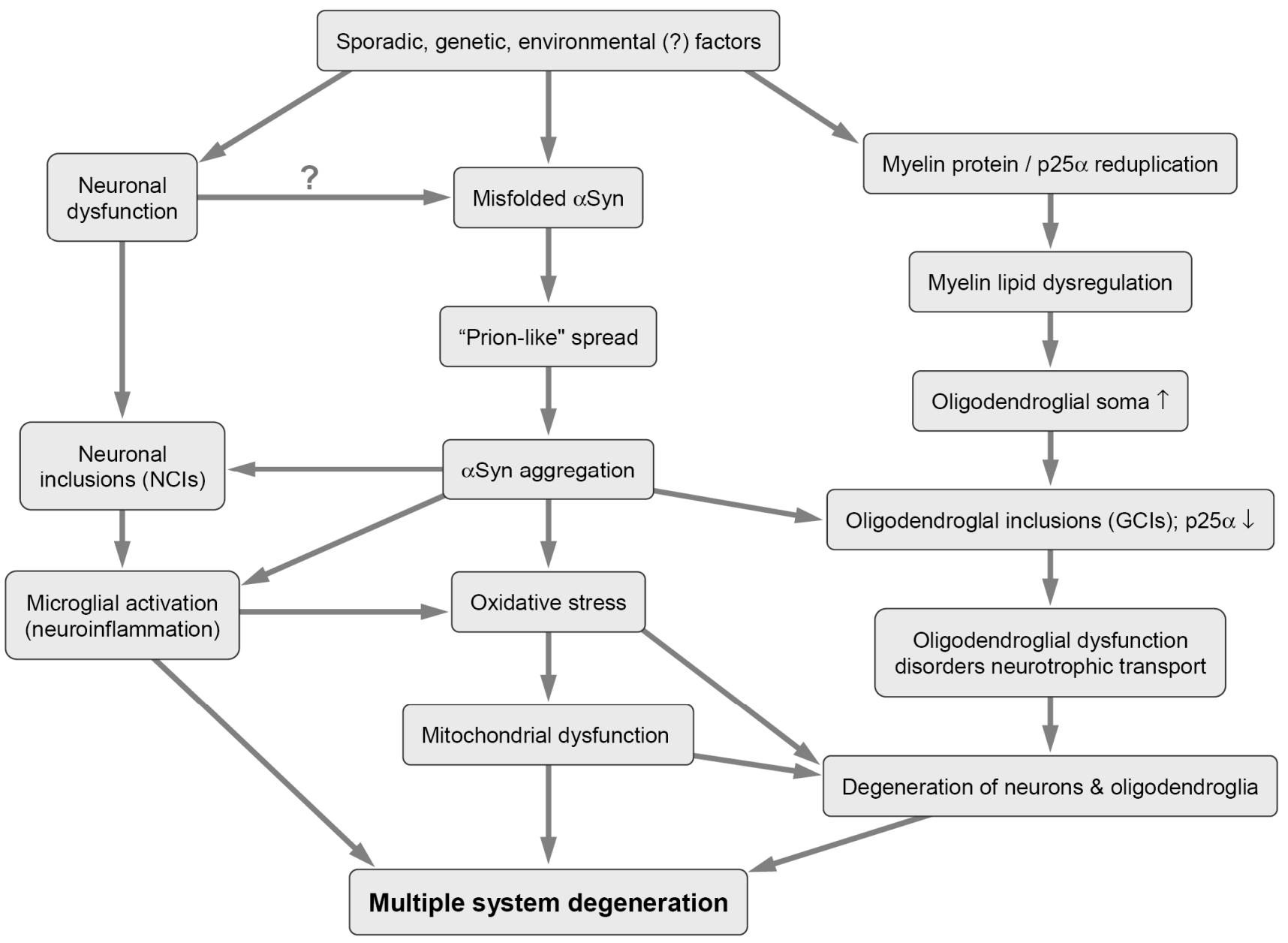

Figure 1. Putative pathogenic pathways of multiple system atrophy. NCIs: neuronal cytoplasmic inclusions; GCIs: glial cytoplasmic inclusions; $\alpha$ Syn: $\alpha$-synuclein.

\section{2. "Typical" MSA}

MSA is a rare disease with an estimated incidence of $0.6-0.7$ and a range of $0.1-2.4$ cases $/ 100,000$ person-years [17]. Disease onset is $56 \pm 9$ years, with both sexes equally affected [18], but 20-75\% of patients have a prodromal/preclinical phase with non-motor, mainly autonomic symptoms (cardiovascular, gastrointestinal, sexual or urogenital dysfunctions, orthostatic hypotension, or REM sleep behavior disorder /RBD/), which may precede motor presentation by years $[19,20]$. The mean survival from the onset of symptoms is 6-10 (mean 9.5) years, with only few patients surviving more than 15 years [21]. Parkinsonism with rigidity, bradykinesia, postural instability, a gait disorder tendency to fall and dysarthria dominates the motor presentation of MSA-P, while tremor is rare [22]. Hyperreflexia and Babinski signs occur in up to 50\%, whereas abnormal postures like antecollis or dystonia are rare [23]. Cerebellar ataxia, widespread gait, uncoordinated 
limb movements, action tremor and spontaneous or gaze-invoked nystagmus predominate MSA-C [24]. These patients usually have a shorter delay with disease duration, RBD prevalence and cognitive assessment scores being similar, while the burden of autonomic symptoms is usually higher in MSA-P patients [25]. It should be emphasized, however, that about $50 \%$ of MSA-P patients develop cerebellar signs and even a higher proportion of MSA-C cases present parkinsonian features [26]. Respiratory disturbances, including inspiratory stridor and sleep apnea, are frequent [21] and are associated with a shortened lifespan and sudden death [20]. Dementia and hallucinations were previously considered as exclusion criteria for the diagnosis of MSA [2], but cognitive impairment has been increasingly reported in recent years $[27,28]$.

The 18-FDG PET studies of patients with "probable" MSA revealed three different profiles, based on different brain metabolic activities: (1) extrapyramidal, axial, laryngeal-pharyngeal involvement (LPI) with cerebellar symptoms; (2) cerebellar and LPI symptoms; (3) cerebellar and cognitive symptoms [29].

The neuropathology of MSA-P shows frontal atrophy, severe atrophy and discoloration of the striatum, and depigmentation of the substantia nigra (SN) and locus ceruleus (LC), whereas MSA-C presents atrophy of the paleo- and neocerebellum, superior cerebellar peduncle, basis pontis and inferior olivary nucleus. Both phenotypes with a similar disease severity and duration have a differential distribution of gray and white matter atrophy, but white matter impairment is more severe in MSA than previously thought [30]. Rare Levodopa responders show a relatively slow progression in putaminal neurodegeneration [31]. Although cerebellar atrophy is a clear differentiation between groups, thalamic and basal ganglia structures are also relevant contributors to distinguish MSA subtypes [32]. The histological core features encompass (1) specific $\alpha$ Syn immunoreactive pathology with five types of inclusions: GCIs within oligodendroglia (Papp-Lantos bodies), which are mandatory for the postmortem diagnosis of MSA [4], and less frequent glial and neuronal nuclear inclusions (GCIs, neuronal cytoplasmic inclusions /NCIs), astroglial cytoplasmic inclusions, and neuronal threads [33]; (2) selective neuronal loss and axonal degeneration involving multiple regions of the nervous system; (3) widespread myelin degeneration with pallor, reduction of the myelin basic protein (MBP) and astrogliosis; and (4) extensive microglial activation and neuroinflammation with diffuse T-cell infiltration in the affected regions [34,35]. GCIs and the resulting neurodegeneration show a characteristic distribution, involving not only the striatonigral and OPC systems, but also multiple cortical regions, autonomic and motor nuclei in brainstem, as well as spinal cord autonomic nerve structures and the peripheral nervous system [1,36,37], characterizing MSA as a multi-system/-organ disorder [1,38].

\section{Atypical MSA or Variants}

Although all cases of MSA display neuronal loss in both striatonigral and olivopontocerebellar structures [39], with only 11 of 42 cases assigned in the category of "pure" MSA [40], this disorder has a wide range of clinical and pathological presentations, which expands the list of differential diagnoses [41]. Several subtypes do not fit into the current classification of MSA [42]: (1) MSA groups with different ages at onset and disease duration; (2) a "minimal change" or "preclinical" MSA as early pathological forms; (3) rare familial forms; (4) pathological variants, like MSA with Lewy body disease and with severe hippocampal atrophy or those with unusual tau pathology; (5) MSA with cognitive impairment/dementia; (6) MSA with dystonia and spinal myoclonus; (7) MSA-C with questionable conjugal MSA.

The reasons for the clinical and morphological heterogeneity of MSA are a matter of current discussion. Possible pathogenic mechanisms could be the recently described diversity in $\alpha$ Syn species and differences in their seeding propensities in different brain regions from synucleinopathies [43], and the distinct biochemical properties of PD and MSA $\alpha$ Syn conformers, which is consistent with the idea that distinct $\alpha$ Syn strains underlie the heterogeneity among the synucleinopathies, e.g., PD and MSA [10,44]. Recent studies 
indicate that $\alpha$ Syn is the most enriched protein in PD and MSA extracts, which share a considerable overlap of their sarkosyl-insoluble protein, consisting of a vast majority of mitochondrial and synaptic proteins, while other fibrillary-prone protein candidates, possibly cross-seeded by $\alpha$ Syn, are neither found in PD nor MSA extracts. These results support the idea that pre-assembled building blocks originating in neurons are involved in the formation of GCIs in MSA and point to the sequestration of mitochondria and of neuronal synaptic components in both LBs and GCIs [45].

A comparison between young and aged mice injected with $\alpha$ Syn preformed fibrils (PFFs) showed that $\alpha$ Syn post-injection (PI) intervals rather than aging correlate with oligodendroglial $\alpha$ Syn deposition. These and other results provide a novel insight into the pathogenetic mechanisms of oligodendroglial $\alpha$ Syn aggregation in MSA [46]. Other recent studies showing a wider heterogeneity of $\alpha$ Syn seeding in MSA could explain a subclassification of MSA, which exceeds conventional clinical and neuropathological phenotyping and is related to the structural and biochemical heterogeneity of the accumulated $\alpha$ Syn [47]. These data support a model whereby the heterogeneity both between different brain regions and between different MSA patients might be due to differences in the cellular environment [48,49], and the presence of posttranslational modifications of $\alpha$ Syn [50] or other cofactors, such as p25 $\alpha$, an oligodendrocyte-specific protein [51], that may confer a selective pressure for one $\alpha$ Syn conformer over another [48]. Other studies have shown that the overexpression of $\alpha$ Syn by oligodendrocytes in transgenic mice does not recapitulate the fibrillary aggregation seen in GCIs in a human MSA brain, which could help to establish a link between $\alpha$ Syn aggregation in the development of a clinical phenotype of MSA [52].

\section{Young-Onset MSA}

Young-onset MSA (YOMSA) is rare. Among 455 patients, four $(0.9 \%)$ developed the disease before the age of 40 [53]. Two presented with cerebellar symptoms, one of whom had a course typical of MSA, the other patient, after a rapid deterioration, died 3 years after disease onset. Two others presented with Levodopa-responsive parkinsonism, later developing motor fluctuations and peak-dose dyskinesias. Subthalamic brain stimulation resulted in the mild improvement of motor symptoms, but later deterioration occurred. There were no distinguishing clinical features for YOMSA in terms of presenting symptoms or survival, but a tendency to develop motor complications. Unfortunately, no autopsy data were available. Another group reported 22 patients with YOMSA, eight of whom with pathological confirmation [54]. These patients showed both clinical and pathological differences versus late-onset MSA (LOMSA), i.e., more common dystonia, Levodopa induced dyskinesias and pyramidal signs, whereas at postmortem analysis, the "minimal change variant" [55] was more common than in LOMSA, with a mean survival of $11.1 \pm 3.2$ (range 5.5-14.6) years). Among 44 autopsy-proven cases (24 MSA-P, 20 MSA-C), two showed disease onset before age 40 . A female aged 33 years developed typical parkinsonism with a moderate transient Levodopa response, but progressive deterioration with autonomic failure, limb contractures, mild dementia and death in a decerebrate state 9 years after disease onset. Neuropathology revealed SND stage III [40] with generalized GCIs, occasional LBs but an intact OPC system. A male at age 39 developed orthostatic hypotension, mild cerebellar ataxia, increasing rigidity without tremor, bradykinesia, pyramidal signs and limb contractures, with death 9 years after disease onset. Neuropathology revealed SND and OPCA (both grade III), and a generalized GCI burden but no LBs; diagnosis was MSA-C+P associated with spino-cerebellar degeneration [56]. In comparison to the above YOMSA group, these patients presented with slow clinical progression and progressed pathological changes, suggesting various clinical and pathological phenotypes of YOMSA.

\section{Later-Onset MSA (LOMSA)}

Although in the consensus guidelines for the diagnosis of MSA [2], onset after age 75 is considered a non-supporting feature, some patients present with initial symptoms after age 75 [57,58]. Among 1425 clinically probable MSA patients in Korea, 39 had a mean 
onset at 76.8 years, with more frequent MSA-P (64.1\%) than MSA-P in the mean-age at the onset group (40.6\%). Dysautonomic symptoms, falls, limb ataxia and speech disturbance were more common in the LOMSA group. These patients had a shorter survival than the others. Among autopsy-proven cases, the SND dominant type was more common in the LOMSA group [57]. Among 171 autopsy-confirmed MSA cases in the Mayo Clinic brain bank (133 MSA-P, 35 MSA-C, 2 unclassified), six patients had LOMSA [58].

According to a recent study, LOMSA patients showed poor prognosis with a median survival time of 3 years, which is significantly shorter than in those with usual onset MSA (UOMSA) (4.8 vs. 7.9 and 3.9 vs. 7.5 years, respectively) [59]. Among 276 patients (193 in an autopsy cohort and 83 in a clinical cohort), LOMSA accounted for $8 \%$ and $5 \%$, respectively. These and other studies showed that the clinical diagnosis of MSA may be difficult in elderly individuals due to the paucity of autonomic symptoms. All LOMSA patients presented with initial motor symptoms and had a more rapid disease progression than YOMSA patients, whereas no essential differences in the neuropathology of both cohorts were reported. Among 48 autopsy-confirmed cases of MSA (33 MSA-P and 15 MSA-C), with a mean age at disease onset of $55.5 \pm 6.5$ years, two females (both MSA-P) showed disease onset at age 75 and 80, respectively. The time from diagnosis to death was 2 and 4 years, respectively. In both patients the initial symptoms were gait disorders, bradykinesia and falls, without essential autonomic symptoms (orthostatic hypotension, urinary difficulties, etc.) or cerebellar signs. The clinical diagnosis was MSA-P, with the Hoehn \& Yahr IV stage at the last visit. Both patients showed considerable cognitive impairment. Neuropathology showed SND grade III, associated with tau pathology akin to neuritic Braak stage III and V, respectively, and moderate cerebral amyloid angiopathy (CAA) [60]. In conclusion, these cases confirm previous observations showing that rare MSA patients with a late age of disease onset differ from the majority of MSA patients with a younger age of onset by mainly initial extrapyramidal syndromes without considerable autonomic symptoms and poorer prognosis, i.e., significantly shorter survival [61]. Cognitive impairment/dementia in these elderly MSA patients may be caused by considerable Alzheimer-related (and other) co-pathologies.

\section{MSA with Prolonged Survival}

MSA is a rapidly progressive disorder with a mean survival of 6-10 years, while $2-3 \%$ have a prolonged survival of 15 years and more [53,62]. Most of these patients had similar disease courses with a slow progression of parkinsonism in the first years and a subsequent rapid deterioration with the development of autonomic failure, making an accurate diagnosis of MSA difficult. Many of them developed motor fluctuations and Levodopa induced dyskinesias. Patients with MSA-P with slow progression and prolonged survival were considered as "benign" forms of MSA [62]. In a woman aged 82 years with a clinical course of 18 years, extensive distribution of GCIs along with NCIs involved the neocortex and limbic system. In particular, the granular cell layer of the dentate gyrus [63]. These findings were different from three MSA cases with disease durations of 15-19 years, showing the typical involvement of the striatonigral and OPC systems, but only a mild to moderate GCI burden without evident neuronal loss in the neocortex, hippocampus and amygdala [64]. A recently published case of MSA, with a 20-year disease duration, at autopsy showed severe gliosis and neuronal loss in a typical pattern, with atypical Pick body-like and ring-shaped $\alpha$ Syn inclusions, most prominent in limbic structures [65], consistent with a rare "atypical MSA" subtype. A Vietnamese woman aged 45 years, who died 21 years after her initial diagnosis of MSA-P, at autopsy showed both SND and OPCA with additional frontal and limbic atrophy, pathognomonic inclusions and Pick body and neurofibrillary tangle (NFT)-like $\alpha$ Syn-positive inclusions in the hippocampus, consistent with long-standing MSA-P with a limbic and frontotemporal lobar degeneration (FTLD)-type $\alpha$ Syn pathology [66]. An atypical case of FTLD-TDP type A with MSA phenocopy showed severe SND and cerebellar involvement [67], while four cases with clinical features of FTLD without autonomic dysfunction, presented frontotemporal atrophy and severe limbic $\alpha$ Syn neuronal pathology with Pick body-like but tau-negative 
inclusions. They were suggested representing a novel subtype of FTLD associated with $\alpha$ Syn pathology [66]. These observations indicate a highly variable involvement of different CNS areas in the rare cases of MSA with a prolonged clinical course.

\section{7. "Minimal Change" MSA}

This aggressive form with GCIs and neurodegeneration almost restricted to the SN, putamen and LC, thus representing "pure" SND [68-73], indicates that GCI formation is an early event and may precede neuronal loss, thus being responsible for some of the clinical symptoms. One patient with preclinical MSA-C showed abundant GCIs in the pontine nuclei, middle cerebellar peduncle and cerebellar white matter, whereas NCIs restricted to the pontine basis, cerebellar vermis and inferior olivary nuclei were associated with neuronal loss, suggesting a link between both lesions in early stages of disease [74]. These patients presenting only mild clinical symptoms were recently suggested to represent "early MSA" rather than "minimal change" MSA [75]. Early MSA stages show a widespread increase of microglia (about 100\%) in the white matter [76] without concomitant astrogliosis or essential oligodendroglial degeneration [77]. Both microglial activation and $\alpha$ Syn containing oligodendrocytes trigger neuroinflammation restricted to white matter regions with the preservation of gray matter areas [34]. A non-motor variant of pathologically confirmed MSA showed no overt parkinsonian or cerebellar signs [78]. The coexistence of the sporadic Creutzfeldt-Jakob disease with "minimal change" MSA was reported in a Spanish woman aged 64 [79]. A limbic counterpart of "minimal change" MSA with abundant $\alpha$ Syn pathology in the limbic system was reported in a male aged 70 with an onset of stiffness and swallowing difficulties at age 65. Based on symmetrical parkinsonism without tremor, dysphagia and autonomic failure, the clinical diagnosis was MSA. At autopsy, GCIs and NCIs were distributed throughout the brain with severe affection of limbic structures, especially the hippocampus, whereas the striatonigral and OPC systems showed only sparse inclusions. Therefore, the neuropathological diagnosis was "minimal change" MSA with limbic predominant $\alpha$ Syn [80]. This case implies not only the striatonigral or OPC, but also the limbic system can be predominantly involved in this rare subtype of MSA.

In neurologically normal individuals, GCIs are rarely found at autopsy as coincidental or incidental findings limited to the pons and inferior olivary nuclei with mild neuronal loss in SN, suggesting that these regions may be afflicted first in MSA-P [72,73]. In early MSA, the white matter microstructure was more affected than the gray matter. These changes were greater in MSA-C than in MSA-P, suggesting variable deterioration in the subtypes of MSA-C [81]. The presence of GCIs may represent an age-related phenomenon not necessarily progressing to overt neurological disease, classifying these cases as "prodromal/preclinical" or "incidental" MSA, similar to incidental LBD [82]. A recent data-driven classification of patients with early-stage MSA identified three subtypes. Almost half of them showed marked autonomic dysfunction and moderate parkinsonism, whereas the others presented with predominant parkinsonism or cerebellar symptoms but mild dysautonomia [83].

\section{Familial MSA}

MSA is generally considered a sporadic disorder, and a family history of ataxia or parkinsonism has been defined as a non-supporting feature in the current diagnostic criteria [2], but MSA pedigrees with both autosomal-dominant and autosomal-recessive inheritance have been observed in Europe and Asia [84-88], and there are reports of autopsy-proven MSA [89]. A genome-wide association study (GWAS) found an estimated heritability of $2-7 \%$ [90], but no single mutation linked to familial forms has been identified [24]. The link between V393A mutations and the COQ2 gene, encoding the coenzyme Q10 (COQ10) and familial or sporadic MSA in Japanese and other Asian populations [91-96], has not been confirmed in other populations [90,97-99]. The COQ2 V393A variant remains a susceptibility risk rather than causative, particularly for the MSA-C subtype in the east Asian population [100]. The TBP CAG/CAA repeat length of longer 
alleles (>38 repeats) is associated with an increased MSA risk, which supports a possible genetic overlap of MSA with spinocerebellar ataxia/SCA17 [101], causing the possibility of a misdiagnosis between MSA and SCAs [102]. Rare cases in a family with a pathological hexanucleotide repeat expansion in C9orf72, a gene linked to amyotrophic lateral sclerosis, presented clinical and neuroimaging features indistinguishable from MSA [103], and this gene may be involved in the heterogeneity of MSA [104].

\section{MSA with Lewy Body Disease}

Although MSA and Lewy body disease (LBD) are clinicopathologically distinct entities within the group of synucleinopathies, clinical presentations can sometimes overlap and some cases of LBD can be misdiagnosed as MSA $[105,106]$, and both may have autonomic dysfunction and RBD. Furthermore, 10.7-22.7\% of patients with MSA have concomitant LBD [8,106-108], but the combination of diffuse LBD and MSA has rarely been reported. Recently, 11 among 230 autopsy-proven MSA cases (5\%) showed the characteristic clinicopathological features of MSA + LBD; seven were the brainstem type, three transitional and one the diffuse LBD type [109]. A case of FTLD-TDP type A with MSA phenocopy had an antemortem diagnosis of PD with dementia (PDD) or probable dementia with Lewy bodies (DLB). Two cases had neuronal loss in SN, but not in striatal or OPC systems, with widespread GCIs consistent with "minimal change" MSA. In these cases, LBD was considered the primary pathology, and MSA as coincidental. APOE $\varepsilon 4$ allele frequency was not different between MSA patients with and without LBD, while 2/9 MSA + LBD patients had a risk variant of the GBA gene. Although rare, MSA with LBD can develop clinical features of PDD or DLB. "Minimal change" MSA could be interpreted as a coincidental but distinct synucleinopathy in a small subset of patients with diffuse LBD. Due to the fact that cognitive impairment/dementia and visual hallucinations occur in some patients with MSA [110,111], it may be difficult to make an exact differential diagnosis between DLB and MSA-P. There may be an overlap in the cognitive profiles of both disorders, although cognitive impairment is more profound in DLB [111], while fluctuating cognition, typical for DLB, appears to be absent in MSA [112]. However, it has been suggested that this feature may have been overlooked in MSA [113]. Although parkinsonism, autonomic dysfunction and RBD can be seen in both MSA and LBD, the presence of dementia and hallucinations, or dementia with RBD and parkinsonism should be considered as red flags for coexisting Lewy-related pathology [114].

\section{MSA with Severe Hippocampal Atrophy}

Although the striatonigral and OPC systems are the most vulnerable regions in MSA, abundant GCI burden and neuronal loss in other regions have been occasionally reported as pathological variants of MSA [66,115-119]. These patients may present with cortical symptoms, including frontotemporal dementia (FTD), corticobasal syndrome or others, which are not presented in classical cases of MSA [66]. Recently, among 146 autopsy-proven cases of MSA from Japanese clinics, 12 patients (8.2\%; 7 MSA-P and 5 MSA-C) showed severe hippocampal pathology due to a heavy burden of $\alpha$ Syn immunoreactive NCIs associated with severe neuronal loss and astrogliosis in the hippocampal granular layer, CA1, subiculum, parahippocampal gyrus and amygdala [120]. The NCIs showed ring-shaped or NFT-like configurations, while three cases presented Pick body-like NCIs and severe atrophy of the medial temporal lobes with heavy NCI burden. In addition, LBs were seen in one of these cases, which showed Braak NFT stages I-III (mean $1.6 \pm 0.8$ ), being slightly higher than in the classical MSA. The patients with hippocampal MSA were younger at disease onset (mean $56.6 \pm 9.3$ vs $60.4 \pm 9.3$ years), had significantly longer disease duration (13.2 \pm 5.9 vs $6.9 \pm 3.0)$ and higher prevalence of cognitive impairment. This hippocampal subtype of MSA was considered a rare pathological variant and not the result of advanced disease. Among 48 autopsy-confirmed MSA (33 MSA-P and 15 MSA-C) with a mean age at disease onset of $55.5 \pm 6.5$ years and mean duration of 7.5 years, two females, both MSA-P and disease onset at age 61 and 75 and disease duration of 4 and 
7 years, respectively, neuropathologically showed a considerable hippocampal pathology. Both patients presented initial rigidity, bradykinesia and gait disorders without tremor or essential autonomic failure. Clinical diagnoses were the PD rigid-akinesia type and MSA-P, respectively, with Hoehn \& Yahr stage 4 to 5 at the last visit. The elder patient developed visual hallucinations, depression and moderate cognitive impairment, later laryngeal stridor and died of pneumonia. The younger lady, in addition to parkinsonian symptoms, developed mild muscular atrophies and a moderate cognitive impairment. Neuropathologically, both cases showed frontal and mediotemporal atrophy, SND grade III, with OPCA grade I in the elder one. In addition to multiple GCIs in the striatum, brainstem and less in the cerebral cortex, severe involvement by NCIs with neuronal loss and astrogliosis was seen predominantly in the hippocampal subarea CA1, granular cell layer, presubiculum, and parahippocampal gyrus. Neither Pick body-, nor NFT-like NCIs nor LBs were observed. In addition, moderate hippocampal tau pathology (Braak stage III) and mild Thal phases $0-2$, but no tau-positive astroglia, cerebral amyloid angiopathy (CAA), TDP-43 co-pathologies or limbic and FTLD-type $\alpha$ Syn pathology were observed. The psychotic symptoms and cognitive impairment in both patients were correlated to the severe hippocampal involvement by $\alpha$ Syn and less by tau pathology. Neuronal mitochondrial dysfunction and altered ribostasis in NCI formation may be involved in the hippocampal degeneration of MSA [121].

\section{MSA with Cognitive Impairment/Dementia}

While cognitive impairment or dementia have been observed in $80-90 \%$ of patients with PD and DLB [1,122-124], they have been considered as exclusion criteria in the diagnosis of MSA [2]. However, a recent position statement by the Neuropathology Task Force of the Movement Society reported that cognitive impairment may occur in 17-47\% of MSA patients, while severe dementia is rare [113]. Mild to moderate cognitive impairment has been reported in up to $40 \%$ in MSA-P patients and in $14.37 \%$ of autopsy-proven MSA cases $[3,8,28,105,115,125]$, with a predominant impairment of executive functions and verbal memory $[126,127]$. In a retrospective study of 102 autopsy-confirmed cases of MSA, $33(32 \%)$ had cognitive impairments, morphologically associated with a greater burden of NCIs in the limbic regions, in particular, in the dentate gyrus than patients without a cognitive impairment [8]. More severe and widespread cognitive dysfunction was seen in MSA-P than in MSA-C patients [128], while according to others, MSA-C patients performed significantly worse [126]. Cognitive impairments in MSA are probably due to involvement of prefrontal areas $[129,130]$ causing striatofrontal dysfunction [131], or severe $\alpha$ Syn pathology in hippocampus $[5,8,120,132]$. Other structural changes in MSA-P patients with a cognitive impairment are cortical thinning, more severe in the fronto-temporal-parietal than in posterior brain regions, and a reduction of the subcortical gray structures [127], globular inclusion in the medial temporal region [115] or corpus callosum involvement [133]. However, others found no pathological differences between MSA patients with and without a cognitive impairment [134]. Only in a few autopsy-proven cases of MSA has ADNC been reported [3,135], while a clinical case of MSA with preexisting AD was observed [136]. Among 48 autopsy-proven cases of MSA (mean age at death $60.5 \pm 7.8$, range $46-82$ years), mild to moderate cognitive impairment in $35.3 \%$ was associated with a moderate cortical tau pathology (Braak NFT stages II-IV) and cortical Lewy pathologies, while one had a probable primary age-related tauopathy (PART). A female aged 82 with a duration of 2 years and severe dementia showed fully developed $\mathrm{AD}$ (Braak stage $\mathrm{V}, \mathrm{ABC} 3 / 3 / 3$ ) and moderate CAA. LBs mainly in SN and LC were seen in 11 brains (20.9\%) and in four of them, also, in the frontal cortex and dorsal nucleus of the vagus [27]. The GCI load in the striatum and the proportion of cases with subcortical small vessel disease did not significantly differ between MSA cases with and without dementia [107]. However, when combined with cerebrovascular risk factors and comorbidities, e.g., those causing autonomic failure, cerebrovascular pathology may masquerade as MSA [109,114]. Considering these findings in a limited number of MSA patients, the diagnosis of MSA requires the exclusion of other 
causes and further studies to elucidate the pathological basis of cognitive impairment in MSA are warranted [28].

\section{MSA with Unusual Tau Pathology}

A recent clinicopathological study of seven cases of MSA, in addition to characteristic morphological findings, demonstrated unusual tau-positive astroglia predominantly in the putamen, internal capsule, and pontine basis. These lesions were prominent in a female aged 72 who died 9 years after the onset of parkinsonism and ataxia [137]. The presence of tau-positive granules not co-localized with $\alpha$ Syn-positive GCIs in the oligodendroglia, with a more common expression of 4-repeat $(R)$ than 3-R tau, and related to the severity of neurodegeneration in MSA, suggested that tau may be related to a neurodegenerative pathway different from that induced by $\alpha$ Syn, which is particularly associated with memory impairment in MSA [132].

Among 48 autopsy-confirmed MSA cases, only in one male aged 67, with 7 years duration of parkinsonism, in addition to SND grade III, tau-positive granules were detected by AT8 immunohistochemistry in the cytoplasm of astroglia in the degenerated putamen. These granules showed both R 3 and R 4 tau positivity, 4R tau being more common. Tau-positive granula were not co-localized with GCIs and double immunostaining showed no co-expression of tau and $\alpha$ Syn. No tau-positive glial granules were observed in any of the other 47 MSA cases, although AD-related lesions of a moderate degree were present in six cases of MSA aged 54-82 years [56]. A few other reports using the AT8 antibody have demonstrated that phosphorylated tau (p-tau) occurs in neurons, astrocytes, and oligodendrocytes of patients with a long disease duration $[117,137,138]$ and atypical MSA cases with FTLD [66]. However, other p-tau sites, except for the epitope AT8 (p-tau 202/205), are less well studied in MSA. With antibodies against p-tau 231 instead of AT8, more numerous signals would be detectable in these MSA cases. The p-tau 231 expression level has been closely correlated with the Braak neuritic stages [139], and increased plasma p-tau 231 levels also correlate with amyloid- $\beta$ pathology and prior to the threshold of amyloid- $\beta$ PET positivity [140].

Two autopsy cases of MSA with tufted astrocyte-like glia (TUALG), a histopathological feature of progressive supranuclear palsy (PSP), a 4-R tauopathy, have been reported [125]. Clinically, both patients showed symptoms atypical of MSA, such as vertical gaze palsy. Neuropathology, in addition to MSA-typical changes, showed TUALGs in cerebral cortices but no other PSP tau pathologies. The coexistence of MSA and PSP is exceedingly rare. One patient with severe cerebellar ataxia, autonomic failure and rigid-akinetic parkinsonism, at autopsy, showed severe neuronal loss with gliosis in the putamen, SN, inferior olive and pontine basis, moderate neuronal loss and gliosis in the globus pallidus and subthalamic nucleus as well as NFTs and tufted astrocytes in the basal ganglia and brainstem. Double-labeling detected $\alpha$ Syn immunoreactivity in oligodendrocytes, phosphorylated tau in neurons and glia in the brainstem, indicating the coexistence of MSA and PSP [141]. Among 290 autopsy cases of PSP screened for $\alpha$ Syn and tau immunohistochemistry, a single case of PSP/MSA was detected. A female aged 86 years with clinical features consistent with PSP showed no signs of dysautonomia or cerebellar symptoms and imaging studies were not consistent with MSA. Neuropathology revealed tau-positive neuronal and glial lesions consistent with PSP as well as an $\alpha$ Syn-positive GCIs diagnostic of MSA. Double immunolabeling revealed no co-localization of $\alpha$ Syn and tau in most glial and neuronal inclusions [142]. Based on these findings, the neuropathological changes of PSP and MSA are distinct and independent processes, but they can occasionally coexist.

The pathogenic impact of tau accumulation in the astroglial cytoplasm is unclear, although links between $\alpha$ Syn and tau are suggested by the co-localization of both proteins in LBs and NFTs [143-145]. Whereas there are strong indications for an interaction between $\alpha$ Syn and tau in PD and other synucleinopathies [146,147], the relationship between these two proteins in specific cases of MSA awaits further elucidation. 


\section{MSA with Dystonia}

In about $40 \%$ of untreated MSA patients anterocollis and unilateral limb dystonia represented the most frequent forms [148]. In five of 24 patients, four of whom with Levodopa responsive MSA-P, neuropathology confirmed the clinical diagnosis. A woman aged 57 with four years duration and unilateral end of dose focal dystonias, at autopsy revealed a minor neuronal depletion in the dorsolateral putamen with a heavy GCI load, severe focal neuron loss in the caudal ventrolateral substantia nigra compacta (SNc), and LC without LBs or pontine involvement, corresponding to MSA-P grade II [40]. In another patient with five years disease duration and craniocervical peak dose dystonia, neuropathology showed similar mild degeneration of the dorsolateral putamen and SNc, while two others with a disease duration of 4 and 5 years, respectively, and a generalized peak of dose dystonia, histopathologically showed subtotal degeneration of the dorsolateral and less of the anterior putamen and caudate nucleus, associated with mild gliosis of the globus pallidus and degeneration of SNc, particularly in the dorsolateral middle and caudal parts, corresponding to MSA-P grade III. A review of autopsy cases of MSA with dystonia in the literature and personal studies demonstrated that among eight cases with anterocollis, five were MSA-P and three MSA-C. All the former were characterized by severe degeneration of the putamen, particularly involving the dorsolateral part, and the SNc. Among 28 cases with generalized spastic dystonia, 21 were MSA-P and 8 MSA-C; 26 of them showed severe degeneration of the putamen, 12 of the caudate nucleus, seven of the globus pallidus, and in all except for one, severe involvement of the SNc. Only single cases showed involvement of the thalamus, corpus subthalamicum and other brainstem nuclei, such as the LC, substantia nigra reticulata, arcuate nucleus, and others. These data demonstrated that dystonia is more frequent in MSA-P than in MSA-C; in most but not in all cases it is associated with the severe degeneration of the dorsolateral putamen and $\mathrm{SNc}$, and less of the ventral putamen. While in MSA with spastic dystonia, both the putamen and SNc appear equally involved, in those with dystonic contractures, the putamen is usually more often affected than the $\mathrm{SNc}$, whereas affection of other subcortical brainstem nuclei and the pontocerebellar system is very rare. This conforms to previous studies on focal dystonia emphasizing the role of the putamen as a major site of this particular dysfunction $[149,150]$, that is related to impairment of the basal ganglia circuitry [151]. However, in view of the variability in the intensity and distribution of the morphological lesions in MSA with dystonia, their pathophysiological mechanisms need further elucidation [152].

\section{MSA with Spinal Myoclonus}

Myoclonus has been reported in MSA with a prevalence ranging from $16.6 \%$ to 95\% [153-155], but its mechanism is not well understood. Among 22 cases of definite MSA-C, three showed myoclonus between one and 6.17 years from symptom onset. Immunohistochemical studies revealed more $\alpha$ Syn deposition in motor-related regions of the spinal cord compared to those without myoclonus [156]. A male aged 66 presenting with dysarthria, ataxia, falls, autonomic dysfunctions and multifocal startle myoclonus died after five years. Neuropathology, in addition to the degeneration of the cerebellum, pontine basis, middle cerebellar peduncles, spinocerebellar and lateral spinal tracts, revealed an abundant $\alpha$ Syn deposition in oligodendroglia in the gray matter of the spinal cord (anterior and posterior horns), and white matter tracts. This case also appears to represent spinal myoclonus in MSA-C caused by the deposition of $\alpha$ Syn in the spinal cord [156], but larger studies will be necessary for understanding the neurobiology of myoclonus in patients with MSA.

\section{Conjugal MSA}

PD in one spouse and MSA in the other have been reported, while a recent paper described a married couple in which both husband and wife developed MSA symptoms at age 63 years. The husband, after developing parkinsonism and global autonomic failure, died at age 66, two years after symptom onset. The wife, at age 63, developed urinary in- 
continence, dysarthria, dysphonia, sleep apnea, parkinsonism and action tremor within one year. It was suggested that this case of conjugal MSA likely occurred by chance, although exposure to shared risk factors (pesticides) could not be excluded [157]. Another case of conjugal MSA-C was reported in a Japanese couple [158]. The wife at age 54 presented with finger movement disorders followed by gait disturbance, postural instability, obstipation, adiadochokinesia, RBD, hyperreflexia, and orthostatic hypotension. A brain CT revealed cerebellar and pontine atrophy indicating probable MSA-C. Two years after her disease onset, the husband, aged 58, presented with gait disturbances, adiadochokinesia and orthostatic hypotension. A brain MRI showed cerebellar and brainstem atrophy, a typical hot cross sign in the pons; SPECT revealed hypoperfusion of the brainstem and cerebellum, suggesting the same diagnosis. The couple denied any environmental risk factors, and genome sequencing excluded any mutations typical for MSA or spinocerebellar ataxia, but evaluation of the genetic risk factors of MSA suggested that the couple, in particular the wife, showed risk alleles in all single nucleotide polymorphism examined. These and other examinations provided no evidence to exclude the possibility of person-to-person transmission. Both these studies of clinically probable conjugal MSA may have important implications for conjugal $\alpha$-synucleinopathies. Even though the transmissibility of MSA in a prion-like pattern is an intriguing hypothesis, considering both the investigated environmental as well as genetic risk factors, they do not allow any definite conclusions in this regard [159].

\section{Conclusions and Outlook}

MSA is a rapid progressive and fatal neurodegenerative disorder with currently no available effective treatment, but its accurate diagnosis is important for the proper management of patients, particularly in the early course of the disease. However, due to the great variability of the clinical presentation based on the neuropathological heterogeneity of MSA, the current clinical diagnostic criteria have some limitations not only in early, but even in progressed stages of the disease, since they do not include recent clinical and laboratory findings which may improve the diagnosis, and do not capture the large number of clinical and morphological variants of MSA [160-165]. These aspects should be taken into consideration when revising the current diagnostic criteria of MSA [41,166]. A critical review of 218 MSA cases showed that $177(81.2 \%)$ were clinically diagnosed and pathologically confirmed as MSA (i.e., typical cases), while the remaining $41(18.8 \%)$ had received alternative clinical diagnoses, including PD $(n=16)$ and PSP $(n=17)$ [167]. It is actually the high rate of disease progression that changes the initial diagnosis of usually PD or other movement disorders to MSA at later clinical visits, while the diagnostic difficulties in prodromal or initial disease stages are much higher [168-170]. Given the modern disease-modifying treatment procedures for MSA being under investigation [160], recognition of an MSA patient in an early phase of the disease as much as possible is urgently warranted.

Funding: The study was funded by the Society for the Promotion of Research in Experimental Neurology, Vienna, Austria.

Institutional Review Board Statement: Not applicable.

Informed Consent Statement: Not applicable.

Acknowledgments: The author thanks E. Mitter-Ferstl for secretarial and graphical work.

Conflicts of Interest: The authors declare no conflict of interest.

\section{Abbreviations}

$\begin{array}{ll}\alpha \text { Syn } & \alpha \text {-synuclein } \\ \text { CNS } & \text { central nervous system } \\ \text { DLB } & \text { dementia with Lewy bodies } \\ \text { FTLD } & \text { frontotemporal lobar degeneration }\end{array}$




$\begin{array}{ll}\text { GCI } & \text { glial cytoplasmic inclusion } \\ \text { LBD } & \text { Lewy body disease } \\ \text { LBs } & \text { Lewy bodies } \\ \text { LC } & \text { locus ceruleus } \\ \text { LOMSA } & \text { late-onset MSA } \\ \text { LPI } & \text { laryngeal-pharyngeal involvement } \\ \text { MSA } & \text { multiple system atrophy } \\ \text { MSA-C } & \text { cerebellar variant MSA } \\ \text { MSA-P } & \text { MSA with predominant parkinsonism } \\ \text { NCI } & \text { neuronal cytoplasmic inclusions } \\ \text { NFT } & \text { neurofibrillary tangle } \\ \text { OPCA } & \text { olivopontocerebellar atrophy } \\ \text { PDD } & \text { Parkinson disease with dementia } \\ \text { PSP } & \text { progressive supranuclear palsy } \\ \text { RBD } & \text { REM sleep behavior disorder } \\ \text { SN } & \text { substantia nigra } \\ \text { SND } & \text { striatonigral degeneration } \\ \text { UOMSA } & \text { usual onset MSA } \\ \text { YOMSA } & \text { young-onset MSA }\end{array}$

\section{References}

1. Jellinger, K.A. Multiple system atrophy: An oligodendroglioneural synucleinopathy. J. Alzheimers Dis. 2018, 62, 1141-1179. [CrossRef] [PubMed]

2. Gilman, S.; Wenning, G.K.; Low, P.A.; Brooks, D.J.; Mathias, C.J.; Trojanowski, J.Q.; Wood, N.W.; Colosimo, C.; Durr, A.; Fowler, C.J.; et al. Second consensus statement on the diagnosis of multiple system atrophy. Neurology 2008, 71, 670-676. [CrossRef] [PubMed]

3. Wenning, G.K.; Tison, F.; Ben Shlomo, Y.; Daniel, S.E.; Quinn, N.P. Multiple system atrophy: A review of 203 pathologically proven cases. Mov. Disord. 1997, 12, 133-147. [CrossRef] [PubMed]

4. Trojanowski, J.Q.; Revesz, T. Proposed neuropathological criteria for the post mortem diagnosis of multiple system atrophy Neuropathol. Appl. Neurobiol. 2007, 33, 615-620. [CrossRef] [PubMed]

5. Cykowski, M.D.; Coon, E.A.; Powell, S.Z.; Jenkins, S.M.; Benarroch, E.E.; Low, P.A.; Schmeichel, A.M.; Parisi, J.E. Expanding the spectrum of neuronal pathology in multiple system atrophy. Brain 2015, 138, 2293-2309. [CrossRef]

6. Palma, J.A.; Vernetti, P.M.; Perez, M.A.; Krismer, F.; Seppi, K.; Fanciulli, A.; Singer, W.; Low, P.; Biaggioni, I.; Norcliffe-Kaufmann, L.; et al. Limitations of the Unified Multiple System Atrophy Rating Scale as outcome measure for clinical trials and a roadmap for improvement. Clin. Auton. Res. 2021, 31, 157-164. [CrossRef] [PubMed]

7. Shimohata, T. Diagnosis of multiple system atrophy for establishing disease-modifying therapies. Brain Nerve 2020, 72, 131-136. (In Japanese)

8. Koga, S.; Parks, A.; Uitti, R.J.; van Gerpen, J.A.; Cheshire, W.P.; Wszolek, Z.K.; Dickson, D.W. Profile of cognitive impairment and underlying pathology in multiple system atrophy. Mov. Disord. 2017, 32, 405-413. [CrossRef]

9. Jellinger, K.A.; Wenning, G.K.; Stefanova, N. Is multiple system atrophy a prion-like disorder? Int. J. Mol. Sci. 2021, $22,10093$. [CrossRef]

10. Lau, A.; So, R.W.L.; Lau, H.H.C.; Sang, J.C.; Ruiz-Riquelme, A.; Fleck, S.C.; Stuart, E.; Menon, S.; Visanji, N.P.; Meisl, G.; et al. alpha-Synuclein strains target distinct brain regions and cell types. Nat. Neurosci. 2020, 23, 21-31. [CrossRef]

11. Goedert, M.; Jakes, R.; Spillantini, M.G. The synucleinopathies: Twenty years on. J. Parkinsons Dis. 2017, 7, S53-S71. [CrossRef]

12. Dhillon, J.S.; Trejo-Lopez, J.A.; Riffe, C.; McFarland, N.R.; Hiser, W.M.; Giasson, B.I.; Yachnis, A.T. Dissecting alpha-synuclein inclusion pathology diversity in multiple system atrophy: Implications for the prion-like transmission hypothesis. Lab. Investig. 2019, 99, 982-992. [CrossRef] [PubMed]

13. Monzio Compagnoni, G.; Di Fonzo, A. Understanding the pathogenesis of multiple system atrophy: State of the art and future perspectives. Acta Neuropathol. Commun. 2019, 7, 113. [CrossRef] [PubMed]

14. Kaji, S.; Maki, T.; Ishimoto, T.; Yamakado, H.; Takahashi, R. Insights into the pathogenesis of multiple system atrophy: Focus on glial cytoplasmic inclusions. Transl. Neurodegener. 2020, 9, 7. [CrossRef] [PubMed]

15. Woerman, A.L.; Watts, J.C.; Aoyagi, A.; Giles, K.; Middleton, L.T.; Prusiner, S.B. alpha-Synuclein: Multiple system atrophy prions Cold Spring Harb. Perspect. Med. 2018, 8, a024588. [CrossRef] [PubMed]

16. Williams, G.P.; Marmion, D.J.; Schonhoff, A.M.; Jurkuvenaite, A.; Won, W.J.; Standaert, D.G.; Kordower, J.H.; Harms, A.S. T cell infiltration in both human multiple system atrophy and a novel mouse model of the disease. Acta Neuropathol. 2020, 139, 855-874. [CrossRef] [PubMed]

17. Bower, J.H.; Maraganore, D.M.; McDonnell, S.K.; Rocca, W.A. Incidence of progressive supranuclear palsy and multiple system atrophy in Olmsted County, Minnesota, 1976 to 1990. Neurology 1997, 49, 1284-1288. [CrossRef] [PubMed]

18. Quinn, N. Multiple system atrophy-The nature of the beast. J. Neurol. Neurosurg. Psychiatry 1989, 52, 78-89. [CrossRef] [PubMed] 
19. Jecmenica-Lukic, M.; Poewe, W.; Tolosa, E.; Wenning, G.K. Premotor signs and symptoms of multiple system atrophy. Lancet Neurol. 2012, 11, 361-368. [CrossRef]

20. Ralls, F.; Cutchen, L. Respiratory and sleep-related complications of multiple system atrophy. Curr. Opin. Pulm. Med. 2020, 26, 615-622. [CrossRef]

21. Fanciulli, A.; Wenning, G.K. Multiple-system atrophy. N. Engl. J. Med. 2015, 372, 249-263. [CrossRef] [PubMed]

22. Krismer, F.; Wenning, G.K. Multiple system atrophy: Insights into a rare and debilitating movement disorder. Nat. Rev. Neurol. 2017, 13, 232-243. [CrossRef] [PubMed]

23. Köllensperger, M.; Geser, F.; Seppi, K.; Stampfer-Kountchev, M.; Sawires, M.; Scherfler, C.; Boesch, S.; Mueller, J.; Koukouni, V.; Quinn, N.; et al. Red flags for multiple system atrophy. Mov. Disord. 2008, 23, 1093-1099. [CrossRef] [PubMed]

24. Fanciulli, A.; Stankovic, I.; Krismer, F.; Seppi, K.; Levin, J.; Wenning, G.K. Multiple system atrophy. Int. Rev. Neurobiol. 2019, 149, 137-192. [PubMed]

25. Vernetti, P.M.; Palma, J.-A.; Fanciulli, A.; Krismer, F.; Singer, W.; Low, P.A.; Pellecchia, M.T.; Kim, H.-J.; Shibao, C.A.; Peltier, A.; et al. Cerebellar and parkinsonian phenotypes of multiple system atrophy: Differences and similarities at baseline from the Natural History Study of the Synucleinopathies. Neurology 2020, 94, 5054.

26. Wenning, G.K.; Geser, F.; Krismer, F.; Seppi, K.; Duerr, S.; Boesch, S.; Kollensperger, M.; Goebel, G.; Pfeiffer, K.P.; Barone, P.; et al The natural history of multiple system atrophy: A prospective European cohort study. Lancet Neurol. 2013, 12, 264-274. [CrossRef]

27. Jellinger, K.A. Neuropathological findings in multiple system atrophy with cognitive impairment. J. Neural. Transm. 2020, 127, 1031-1039. [CrossRef]

28. Kim, H.J.; Jeon, B.S.; Kim, Y.E.; Kim, J.Y.; Kim, Y.K.; Sohn, C.H.; Yun, J.Y.; Jeon, S.; Lee, J.M.; Lee, J.Y. Clinical and imaging characteristics of dementia in multiple system atrophy. Parkinsonism Relat. Disord. 2013, 19, 617-621. [CrossRef]

29. Grimaldi, S.; Boucekine, M.; Witjas, T.; Fluchere, F.; Renaud, M.; Azulay, J.P.; Guedj, E.; Eusebio, A. Multiple system atrophy: Phenotypic spectrum approach coupled with brain 18-FDG PET. Parkinsonism Relat. Disord. 2019, 67, 3-9. [CrossRef]

30. Del Campo, N.; Phillips, O.; Ory-Magne, F.; Brefel-Courbon, C.; Galitzky, M.; Thalamas, C.; Narr, K.L.; Joshi, S.; Singh, M.K.; Péran, P.; et al. Broad white matter impairment in multiple system atrophy. Hum. Brain Mapp. 2021, 42, 357-366. [CrossRef]

31. Ishida, C.; Takahashi, K.; Kato-Motozaki, Y.; Tagami, A.; Komai, K. Effectiveness of levodopa in patients with multiple system atrophy and associated clinicopathological features. Intern. Med. 2021, 60, 367-372. [CrossRef] [PubMed]

32. Campabadal, A.; Abos, A.; Segura, B.; Monte-Rubio, G.; Perez-Soriano, A.; Giraldo, D.M.; Muñoz, E.; Compta, Y.; Junque, C.; Marti, M.J. Differentiation of multiple system atrophy subtypes by gray matter atrophy. J. Neuroimaging 2022, 32, 80-89. [CrossRef] [PubMed]

33. Wenning, G.K.; Jellinger, K.A. The role of alpha-synuclein in the pathogenesis of multiple system atrophy. Acta Neuropathol. 2005, 109, 129-140. [CrossRef] [PubMed]

34. Hoffmann, A.; Ettle, B.; Battis, K.; Reiprich, S.; Schlachetzki, J.C.M.; Masliah, E.; Wegner, M.; Kuhlmann, T.; Riemenschneider, M.J.; Winkler, J. Oligodendroglial a-synucleinopathy-driven neuroinflammation in multiple system atrophy. Brain Pathol. 2019, 29, 380-396. [CrossRef] [PubMed]

35. Kiely, A.P.; Murray, C.E.; Foti, S.C.; Benson, B.C.; Courtney, R.; Strand, C.; Lashley, T.; Holton, J.L. Immunohistochemical and molecular investigations show alteration in the inflammatory profile of multiple system atrophy brain. J. Neuropathol. Exp. Neurol. 2018, 77, 598-607. [CrossRef]

36. Wakabayashi, K.; Mori, F.; Tanji, K.; Orimo, S.; Takahashi, H. Involvement of the peripheral nervous system in synucleinopathies, tauopathies and other neurodegenerative proteinopathies of the brain. Acta Neuropathol. 2010, 120, 1-12. [CrossRef]

37. Kuzdas-Wood, D.; Irschick, R.; Theurl, M.; Malsch, P.; Mair, N.; Mantinger, C.; Wanschitz, J.; Klimaschewski, L.; Poewe, W.; Stefanova, N.; et al. Involvement of peripheral nerves in the transgenic plp-alpha-syn model of multiple system atrophy: Extending the phenotype. PLOS ONE 2015, 10, e0136575. [CrossRef]

38. Jellinger, K.A. Multiple system atrophy-A clinicopathological update. Free Neuropathol. 2020, 1, 17. [CrossRef]

39. Ozawa, T.; Onodera, O. Multiple system atrophy: Clinicopathological characteristics in Japanese patients. Proc. Jpn. Acad. Ser. B Phys. Biol. Sci. 2017, 93, 251-258. [CrossRef]

40. Jellinger, K.A.; Seppi, K.; Wenning, G.K. Grading of neuropathology in multiple system atrophy: Proposal for a novel scale. Mov. Disord. 2005, 20, S29-S36. [CrossRef]

41. Kim, H.J.; Jeon, B.S.; Jellinger, K.A. Diagnosis and differential diagnosis of MSA: Boundary issues. J. Neurol. 2015, 262, 1801-1813 [CrossRef] [PubMed]

42. Watanabe, H.; Riku, Y.; Nakamura, T.; Hara, K.; Ito, M.; Hirayama, M.; Yoshida, M.; Katsuno, M.; Sobue, G. Expanding concept of clinical conditions and symptoms in multiple system atrophy. Rinsho Shinkeigaku 2016, 56, 457-464. [CrossRef]

43. Poggiolini, I.; Erskine, D.; Vaikath, N.N.; Ponraj, J.; Mansour, S.; Morris, C.M.; El-Agnaf, O.M.A. RT-QuIC using C-terminally truncated alpha-synuclein forms detects differences in seeding propensity of different brain regions from synucleinopathies. Biomolecules 2021, 11, 820. [CrossRef] [PubMed]

44. Yamasaki, T.R.; Holmes, B.B.; Furman, J.L.; Dhavale, D.D.; Su, B.W.; Song, E.S.; Cairns, N.J.; Kotzbauer, P.T.; Diamond, M.I. Parkinson's disease and multiple system atrophy have distinct alpha-synuclein seed characteristics. J. Biol. Chem. 2019, 294, 1045-1058. [CrossRef] [PubMed]

45. Laferrière, F.; Claverol, S.; Bezard, E.; De Giorgi, F.; Ichas, F. Similar neuronal imprint and no cross-seeded fibrils in alpha-synuclein aggregates from MSA and Parkinson's disease. NPJ Parkinsons Dis. 2022, 8, 10. [CrossRef] 
46. Uemura, N.; Uemura, M.T.; Lo, A.; Bassil, F.; Zhang, B.; Luk, K.C.; Lee, V.M.; Takahashi, R.; Trojanowski, J.Q. Slow progressive accumulation of oligodendroglial alpha-synuclein (alpha-syn) pathology in synthetic alpha-syn fibril-induced mouse models of synucleinopathy. J. Neuropathol. Exp. Neurol. 2019, 78, 877-890. [CrossRef]

47. Martinez-Valbuena, I.; Visanji, N.P.; Kim, A.; Lau, H.H.C.; So, R.W.L.; Alshimemeri, S.; Gao, A.; Seidman, M.A.; Luquin, M.R.; Watts, J.C.; et al. Alpha-synuclein seeding shows a wide heterogeneity in multiple system atrophy. Transl. Neurodegener. 2022, 11, 7. [CrossRef]

48. Holec, S.A.M.; Woerman, A.L. Evidence of distinct alpha-synuclein strains underlying disease heterogeneity. Acta Neuropathol. 2020, 142, 73-86. [CrossRef]

49. Peng, C.; Gathagan, R.J.; Covell, D.J.; Medellin, C.; Stieber, A.; Robinson, J.L.; Zhang, B.; Pitkin, R.M.; Olufemi, M.F.; Luk, K.C.; et al. Cellular milieu imparts distinct pathological alpha-synuclein strains in alpha-synucleinopathies. Nature 2018, 557, 558-563. [CrossRef]

50. Schweighauser, M.; Shi, Y.; Tarutani, A.; Kametani, F.; Murzin, A.G.; Ghetti, B.; Matsubara, T.; Tomita, T.; Ando, T.; Hasegawa, K.; et al. Structures of alpha-synuclein filaments from multiple system atrophy. Nature 2020, 585, 464-469. [CrossRef]

51. Ferreira, N.; Gram, H.; Sorrentino, Z.A.; Gregersen, E.; Schmidt, S.I.; Reimer, L.; Betzer, C.; Perez-Gozalbo, C.; Beltoja, M.; Nagaraj, M.; et al. Multiple system atrophy-associated oligodendroglial protein p25alpha stimulates formation of novel alpha-synuclein strain with enhanced neurodegenerative potential. Acta Neuropathol. 2021, 142, 87-115. [CrossRef] [PubMed]

52. Laferrière, F.; He, X.; Zinghirino, F.; Doudnikoff, E.; Faggiani, E.; Meissner, W.G.; Bezard, E.; De Giorgi, F.; Ichas, F. Overexpression of alpha-synuclein by oligodendrocytes in transgenic mice does not recapitulate the fibrillar aggregation seen in multiple system atrophy. Cells 2020, 9, 2371. [CrossRef] [PubMed]

53. Kim, H.J.; Jeon, B.S.; Lee, J.Y.; Yun, J.Y.; Kim, Y.E.; Paek, S.H. Young-onset multiple system atrophy. J. Neurol. Sci. 2012, 319, 168-170. [CrossRef] [PubMed]

54. Batla, A.; De Pablo-Fernandez, E.; Erro, R.; Reich, M.; Calandra-Buonaura, G.; Barbosa, P.; Balint, B.; Ling, H.; Islam, S.; Cortelli, P.; et al. Young-onset multiple system atrophy: Clinical and pathological features. Mov. Disord. 2018, 33, 1099-1107. [CrossRef] [PubMed]

55. Wenning, G.K.; Quinn, N.; Magalhaes, M.; Mathias, C.; Daniel, S.E. “Minimal change” multiple system atrophy. Mov. Disord. 1994, 9, 161-166. [CrossRef]

56. Jellinger, K. Unusual tau in MSA. Neuropathology 2012, 32, 110-111. [CrossRef] [PubMed]

57. Lee, Y.H.; Ando, T.; Lee, J.J.; Baek, M.S.; Lyoo, C.H.; Kim, S.J.; Kim, M.; Cho, J.W.; Sohn, Y.H.; Katsuno, M.; et al. Later-onset multiple system atrophy: A multicenter Asian study. Mov. Disord. 2020, 35, 1692-1693. [CrossRef] [PubMed]

58. Koga, S.; Cheshire, W.P.; Tipton, P.W.; Driver-Dunckley, E.D.; Wszolek, Z.K.; Uitti, R.J.; Graff-Radford, N.R.; van Gerpen, J.A.; Dickson, D.W. Clinical features of autopsy-confirmed multiple system atrophy in the Mayo Clinic Florida brain bank. Parkinsonism Relat. Disord. 2021, 89, 155-161. [CrossRef] [PubMed]

59. Sekiya, H.; Koga, S.; Otsuka, Y.; Chihara, N.; Ueda, T.; Sekiguchi, K.; Yoneda, Y.; Kageyama, Y.; Matsumoto, R.; Dickson, D.W. Clinical and pathological characteristics of later onset multiple system atrophy. J. Neurol. 2022, 1-12. [CrossRef]

60. Jellinger, K.A. Late onset MSA differs from younger onset MSA (Letter). J. Neurol. Neurosurg. Psychiatry, 2022; in press.

61. Watanabe, H.; Saito, Y.; Terao, S.; Ando, T.; Kachi, T.; Mukai, E.; Aiba, I.; Abe, Y.; Tamakoshi, A.; Doyu, M.; et al. Progression and prognosis in multiple system atrophy: An analysis of 230 Japanese patients. Brain 2002, 125, 1070-1083. [CrossRef] [PubMed]

62. Petrovic, I.N.; Ling, H.; Asi, Y.; Ahmed, Z.; Kukkle, P.L.; Hazrati, L.N.; Lang, A.E.; Revesz, T.; Holton, J.L.; Lees, A.J. Multiple system atrophy-parkinsonism with slow progression and prolonged survival: A diagnostic catch. Mov. Disord. 2012, 27, 1186-1190. [CrossRef] [PubMed]

63. Masui, K.; Nakata, Y.; Fujii, N.; Iwaki, T. Extensive distribution of glial cytoplasmic inclusions in an autopsied case of multiple system atrophy with a prolonged 18-year clinical course. Neuropathology 2012, 32, 69-76. [CrossRef] [PubMed]

64. Asi, Y.; Petrovic, I.N.; Ling, H.; Ahmed, Z.; Prashanth, L.K.; Hazrati, L.N.; Lang, A.E.; Lees, A.J.; Revesz, T.; Holton, J.L. Long duration multiple system atrophy: A clinico-pathologic study (abs.). Neuropathol. Appl. Neurobiol. 2012, 38, 36.

65. Coughlin, D.G.; Dryden, I.; Goodwill, V.S.; Pizzo, D.P.; Wright, B.; Lessig, S.; Galasko, D.; MacKenzie, I.R.; Hiniker, A. Long-standing multiple system atrophy-Parkinsonism with limbic and FTLD-type alpha-synuclein pathology. Neuropathol. Appl. Neurobiol. 2021. [CrossRef] [PubMed]

66. Aoki, N.; Boyer, P.J.; Lund, C.; Lin, W.L.; Koga, S.; Ross, O.A.; Weiner, M.; Lipton, A.; Powers, J.M.; White, C.L.; et al. Atypical multiple system atrophy is a new subtype of frontotemporal lobar degeneration: Frontotemporal lobar degeneration associated with alpha-synuclein. Acta Neuropathol. 2015, 130, 93-105. [CrossRef]

67. Sousa, A.L.; Taipa, R.; Quinn, N.; Revesz, T.; Melo Pires, M.; Magalhaes, M. Frontotemporal lobar degeneration-TDP with 'multiple system atrophy phenocopy syndrome'. Neuropathol. Appl. Neurobiol. 2017, 43, 533-536. [CrossRef]

68. Berciano, J.; Valldeoriola, F.; Ferrer, I.; Rumia, J.; Pascual, J.; Marin, C.; Rey, M.J.; Tolosa, E. Presynaptic parkinsonism in multiple system atrophy mimicking Parkinson's disease: A clinicopathological case study. Mov. Disord. 2002, 17, 812-816. [CrossRef]

69. Kon, T.; Mori, F.; Tanji, K.; Miki, Y.; Wakabayashi, K. An autopsy case of preclinical multiple system atrophy (MSA-C). Neuropathology 2013, 33, 667-672. [CrossRef]

70. Wenning, G.K.; Ben Shlomo, Y.; Magalhaes, M.; Daniel, S.E.; Quinn, N.P. Clinical features and natural history of multiple system atrophy. An analysis of 100 cases. Brain 1994, 117, 835-845. [CrossRef] 
71. Ling, H.; Asi, Y.T.; Petrovic, I.N.; Ahmed, Z.; Prashanth, L.K.; Hazrati, L.N.; Nishizawa, M.; Ozawa, T.; Lang, A.; Lees, A.J.; et al. Minimal change multiple system atrophy: An aggressive variant? Mov. Disord. 2015, 30, 960-967. [CrossRef] [PubMed]

72. Parkkinen, L.; Hartikainen, P.; Alafuzoff, I. Abundant glial alpha-synuclein pathology in a case without overt clinical symptoms Clin. Neuropathol. 2007, 26, 276-283. [CrossRef]

73. Fujishiro, H.; Ahn, T.B.; Frigerio, R.; DelleDonne, A.; Josephs, K.A.; Parisi, J.E.; Eric Ahlskog, J.; Dickson, D.W. Glial cytoplasmic inclusions in neurologically normal elderly: Prodromal multiple system atrophy? Acta Neuropathol. 2008, 116, 269-275. [CrossRef] [PubMed]

74. Wakabayashi, K.; Mori, F.; Nishie, M.; Oyama, Y.; Kurihara, A.; Yoshimoto, M.; Kuroda, N. An autopsy case of early ("minimal change") olivopontocerebellar atrophy (multiple system atrophy-cerebellar). Acta Neuropathol. 2005, 110, 185-190. [CrossRef] [PubMed]

75. Ahmed, Z.; Asi, Y.T.; Sailer, A.; Lees, A.J.; Houlden, H.; Revesz, T.; Holton, J.L. The neuropathology, pathophysiology and genetics of multiple system atrophy. Neuropathol. Appl. Neurobiol. 2012, 38, 4-24. [CrossRef]

76. Kübler, D.; Wachter, T.; Cabanel, N.; Su, Z.; Turkheimer, F.E.; Dodel, R.; Brooks, D.J.; Oertel, W.H.; Gerhard, A. Widespread microglial activation in multiple system atrophy. Mov. Disord. 2019, 34, 564-568. [CrossRef] [PubMed]

77. Nykjaer, C.; Brudek, T.; Salvesen, L.; Pakkenberg, B. Changes in the cell population in brain white matter in multiple system atrophy. Mov. Disord. 2017, 32, 1074-1082. [CrossRef] [PubMed]

78. Gaig, C.; Iranzo, A.; Tolosa, E.; Vilaseca, I.; Rey, M.J.; Santamaria, J. Pathological description of a non-motor variant of multiple system atrophy. J. Neurol. Neurosurg. Psychiatry 2008, 79, 1399-1400. [CrossRef]

79. Rodriguez-Diehl, R.; Rey, M.J.; Gironell, A.; Martinez-Saez, E.; Ferrer, I.; Sanchez-Valle, R.; Jague, J.; Nos, C.; Gelpi, E. “Preclinical” MSA in definite Creutzfeldt-Jakob disease. Neuropathology 2012, 32, 158-163. [CrossRef]

80. Koga, S.; Dickson, D.W. "Minimal change" multiple system atrophy with limbic-predominant $\hat{\mathrm{I}} \pm$-synuclein pathology. Acta Neuropathol. 2019, 137, 167-169. [CrossRef]

81. Dash, S.K.; Stezin, A.; Takalkar, T.; George, L.; Kamble, N.L.; Netravathi, M.; Yadav, R.; Kumar, K.J.; Ingalhalikar, M.; Saini, J.; et al Abnormalities of white and grey matter in early multiple system atrophy: Comparison of parkinsonian and cerebellar variants. Eur. Radiol. 2019, 29, 716-724. [CrossRef] [PubMed]

82. DelleDonne, A.; Klos, K.J.; Fujishiro, H.; Ahmed, Z.; Parisi, J.E.; Josephs, K.A.; Frigerio, R.; Burnett, M.; Wszolek, Z.K.; Uitti, R.J.; et al. Incidental Lewy body disease and preclinical Parkinson disease. Arch. Neurol. 2008, 65, 1074-1080. [CrossRef] [PubMed]

83. Yang, H.J.; Kim, H.J.; Jung, Y.J.; Yoo, D.; Choi, J.H.; Im, J.H.; Jeon, B. Data-driven subtype classification of patients with early-stage multiple system atrophy. Parkinsonism Relat. Disord. 2022, 95, 92-97. [CrossRef]

84. Itoh, K.; Kasai, T.; Tsuji, Y.; Saito, K.; Mizuta, I.; Harada, Y.; Sudoh, S.; Mizuno, T.; Nakagawa, M.; Fushiki, S. Definite familial multiple system atrophy with unknown genetics. Neuropathology 2014, 34, 309-313. [CrossRef] [PubMed]

85. Hara, K.; Momose, Y.; Tokiguchi, S.; Shimohata, M.; Terajima, K.; Onodera, O.; Kakita, A.; Yamada, M.; Takahashi, H.; Hirasawa, M.; et al. Multiplex families with multiple system atrophy. Arch. Neurol. 2007, 64, 545-551. [CrossRef] [PubMed]

86. Hohler, A.D.; Singh, V.J. Probable hereditary multiple system atrophy-autonomic (MSA-A) in a family in the United States. J. Clin. Neurosci. 2012, 19, 479-480. [CrossRef] [PubMed]

87. Vidal, J.S.; Vidailhet, M.; Derkinderen, P.; Tzourio, C.; Alperovitch, A. Familial aggregation in atypical Parkinson's disease: A case control study in multiple system atrophy and progressive supranuclear palsy. J. Neurol. 2010, 257, 1388-1393. [CrossRef]

88. Fujioka, S.; Ogaki, K.; Tacik, P.M.; Uitti, R.J.; Ross, O.A.; Wszolek, Z.K. Update on novel familial forms of Parkinson's disease and multiple system atrophy. Parkinsonism Relat. Disord. 2014, 20, S29-S34. [CrossRef]

89. Wullner, U.; Abele, M.; Schmitz-Huebsch, T.; Wilhelm, K.; Benecke, R.; Deuschl, G.; Klockgether, T. Probable multiple system atrophy in a German family. J. Neurol. Neurosurg. Psychiatry 2004, 75, 924-925. [CrossRef]

90. Sailer, A.; Scholz, S.W.; Nalls, M.A.; Schulte, C.; Federoff, M.; Price, T.R.; Lees, A.; Ross, O.A.; Dickson, D.W.; Mok, K.; et al. A genome-wide association study in multiple system atrophy. Neurology 2016, 87, 1591-1598. [CrossRef]

91. Chen, X.; Chen, Y.; Wei, Q.; Ou, R.; Cao, B.; Zhao, B.; Shang, H.F. C9ORF72 repeat expansions in Chinese patients with Parkinson's disease and multiple system atrophy. J. Neural Transm. 2016, 123, 1341-1345. [CrossRef] [PubMed]

92. Lin, C.H.; Tan, E.K.; Yang, C.C.; Yi, Z.; Wu, R.M. COQ2 gene variants associate with cerebellar subtype of multiple system atrophy in Chinese. Mov. Disord. 2015, 30, 436-437. [CrossRef]

93. Zhao, Q.; Yang, X.; Tian, S.; An, R.; Zheng, J.; Xu, Y. Association of the COQ2 V393A variant with risk of multiple system atrophy in East Asians: A case-control study and meta-analysis of the literature. Neurol. Sci. 2016, 37, 423-430. [CrossRef] [PubMed]

94. Multiple-System Atrophy Research Collaboration. Mutations in COQ2 in familial and sporadic multiple-system atrophy. N. Engl. J. Med. 2013, 369, 233-244. [CrossRef]

95. Quinzii, C.M.; Hirano, A.; DiMauro, S. Mutant COQ2 in multiple-system atrophy (Comment). N. Engl. J. Med. 2014, 371, 81-82.

96. Ogaki, K.; Koga, S.; Aoki, N.; Lin, W.; Suzuki, K.; Ross, O.A.; Dickson, D.W. Adult-onset cerebello-brainstem dominant form of X-linked adrenoleukodystrophy presenting as multiple system atrophy: Case report and literature review. Neuropathology 2016, 36, 64-76. [CrossRef]

97. Sharma, M.; Wenning, G.; Krüger, R. Mutant COQ2 in multiple-system atrophy (Comment). N. Engl. J. Med. 2014, 371, 80-81. [PubMed] 
98. Ronchi, D.; Di Biase, E.; Franco, G.; Melzi, V.; Del Sorbo, F.; Elia, A.; Barzaghi, C.; Garavaglia, B.; Bergamini, C.; Fato, R.; et al. Mutational analysis of COQ2 in patients with MSA in Italy. Neurobiol. Aging 2016, 45, 213.e1. [CrossRef]

99. Ferguson, M.C.; Garland, E.M.; Hedges, L.; Womack-Nunley, B.; Hamid, R.; Phillips, J.A., III; Shibao, C.A.; Raj, S.R.; Biaggioni, I.; Robertson, D. SHC2 gene copy number in multiple system atrophy (MSA). Clin. Auton. Res. 2014, 24, 25-30. [CrossRef]

100. Porto, K.J.; Hirano, M.; Mitsui, J.; Chikada, A.; Matsukawa, T.; Ishiura, H.; Toda, T.; Kusunoki, S.; Tsuji, S. COQ2 V393A confers high risk susceptibility for multiple system atrophy in East Asian population. J. Neurol. Sci. 2021, 429, 117623. [CrossRef]

101. Wernick, A.I.; Walton, R.L.; Soto-Beasley, A.I.; Koga, S.; Heckman, M.G.; Valentino, R.R.; Milanowski, L.M.; Hoffman-Zacharska, D.; Koziorowski, D.; Hassan, A.; et al. Frequency of spinocerebellar ataxia mutations in patients with multiple system atrophy. Clin. Auton Res. 2021, 31, 117-125. [CrossRef] [PubMed]

102. Li, M.; Ma, Q.; Zhao, X.; Wang, C.; Wu, H.; Li, J.; Yang, W. Dilemma of multiple system atrophy and spinocerebellar ataxias. J. Neurol. 2018, 265, 2764-2772. [CrossRef] [PubMed]

103. Goldman, J.S.; Quinzii, C.; Dunning-Broadbent, J.; Waters, C.; Mitsumoto, H.; Brannagan, T.H., 3rd; Cosentino, S.; Huey, E.D.; Nagy, P.; Kuo, S.H. Multiple system atrophy and amyotrophic lateral sclerosis in a family with hexanucleotide repeat expansions in C9orf72. JAMA Neurol. 2014, 71, 771-774. [CrossRef] [PubMed]

104. Bonapace, G.; Gagliardi, M.; Procopio, R.; Morelli, M.; Quattrone, A.; Brighina, L.; Annesi, G. Multiple system atrophy and C9orf72 hexanucleotide repeat expansions in a cohort of Italian patients. Neurobiol. Aging 2021, 112, 12-15. [CrossRef]

105. Koga, S.; Aoki, N.; Uitti, R.J.; van Gerpen, J.A.; Cheshire, W.P.; Josephs, K.A.; Wszolek, Z.K.; Langston, J.W.; Dickson, D.W. When DLB, PD, and PSP masquerade as MSA: An autopsy study of 134 patients. Neurology 2015, 85, 404-412. [CrossRef]

106. Miki, Y.; Foti, S.C.; Asi, Y.T.; Tsushima, E.; Quinn, N.; Ling, H.; Holton, J.L. Improving diagnostic accuracy of multiple system atrophy: A clinicopathological study. Brain 2019, 142, 2813-2827. [CrossRef]

107. Jellinger, K.A. More frequent Lewy bodies but less frequent Alzheimer-type lesions in multiple system atrophy as compared to age-matched control brains. Acta Neuropathol. 2007, 114, 299-303. [CrossRef]

108. Wenning, G.K.; Ben-Shlomo, Y.; Magalhaes, M.; Daniel, S.E.; Quinn, N.P. Clinicopathological study of 35 cases of multiple system atrophy. J. Neurol. Neurosurg. Psychiatry 1995, 58, 160-166. [CrossRef]

109. Koga, S.; Li, F.; Zhao, N.; Roemer, S.F.; Ferman, T.J.; Wernick, A.I.; Walton, R.L.; Faroqi, A.H.; Graff-Radford, N.R.; Cheshire, W.P.; et al. Clinicopathologic and genetic features of multiple system atrophy with Lewy body disease. Brain Pathol. 2020, 30, 766-778. [CrossRef]

110. Köllensperger, M.; Geser, F.; Ndayisaba, J.P.; Boesch, S.; Seppi, K.; Ostergaard, K.; Dupont, E.; Cardozo, A.; Tolosa, E.; Abele, M.; et al. Presentation, diagnosis, and management of multiple system atrophy in Europe: Final analysis of the European multiple system atrophy registry. Mov. Disord. 2010, 25, 2604-2612. [CrossRef]

111. Kao, A.W.; Racine, C.A.; Quitania, L.C.; Kramer, J.H.; Christine, C.W.; Miller, B.L. Cognitive and neuropsychiatric profile of the synucleinopathies: Parkinson disease, dementia with Lewy bodies, and multiple system atrophy. Alzheimer Dis. Assoc. Disord. 2009, 23, 365-370. [CrossRef]

112. McKeith, I.G.; Dickson, D.W.; Lowe, J.; Emre, M.; O’Brien, J.T.; Feldman, H.; Cummings, J.; Duda, J.E.; Lippa, C.; Perry, E.K.; et al. Diagnosis and management of dementia with Lewy bodies: Third report of the DLB Consortium. Neurology 2005, 65, 1863-1872. [CrossRef] [PubMed]

113. Stankovic, I.; Krismer, F.; Jesic, A.; Antonini, A.; Benke, T.; Brown, R.G.; Burn, D.J.; Holton, J.L.; Kaufmann, H.; Kostic, V.S.; et al. Cognitive impairment in multiple system atrophy: A position statement by the neuropsychology task force of the MDS multiple system atrophy (MODIMSA) study group. Mov. Disord. 2014, 29, 857-867. [CrossRef]

114. Koga, S.; Roemer, S.F.; Tipton, P.W.; Low, P.A.; Josephs, K.A.; Dickson, D.W. Cerebrovascular pathology and misdiagnosis of multiple system atrophy: An autopsy study. Parkinsonism Relat. Disord. 2020, 75, 34-40. [CrossRef]

115. Homma, T.; Mochizuki, Y.; Komori, T.; Isozaki, E. Frequent globular neuronal cytoplasmic inclusions in the medial temporal region as a possible characteristic feature in multiple system atrophy with dementia. Neuropathology 2016, 36, 421-431. [CrossRef]

116. Horoupian, D.S.; Dickson, D.W. Striatonigral degeneration, olivopontocerebellar atrophy and "atypical" Pick disease. Acta Neuropathol. 1991, 81, 287-295. [CrossRef]

117. Piao, Y.S.; Hayashi, S.; Hasegawa, M.; Wakabayashi, K.; Yamada, M.; Yoshimoto, M.; Ishikawa, A.; Iwatsubo, T.; Takahashi, H. Co-localization of alpha-synuclein and phosphorylated tau in neuronal and glial cytoplasmic inclusions in a patient with multiple system atrophy of long duration. Acta Neuropathol. 2001, 101, 285-293. [CrossRef]

118. Rohan, Z.; Rahimi, J.; Weis, S.; Kapas, I.; Auff, E.; Mitrovic, N.; Liberski, P.P.; Sikorska, B.; Matej, R.; Kovacs, G.G. Screening for alpha-synuclein immunoreactive neuronal inclusions in the hippocampus allows identification of atypical MSA (FTLD-synuclein). Acta Neuropathol. 2015, 130, 299-301. [CrossRef]

119. Shibuya, K.; Nagatomo, H.; Iwabuchi, K.; Inoue, M.; Yagishita, S.; Itoh, Y. Asymmetrical temporal lobe atrophy with massive neuronal inclusions in multiple system atrophy. J. Neurol. Sci. 2000, 179, 50-58. [CrossRef]

120. Ando, T.; Riku, Y.; Akagi, A.; Miyahara, H.; Hirano, M.; Ikeda, T.; Yabata, H.; Koizumi, R.; Oba, C.; Morozumi, S.; et al. Multiple system atrophy variant with severe hippocampal pathology. Brain Pathol. 2022, 32, e13002. [CrossRef] [PubMed]

121. Maeda, N.; Honda, H.; Suzuki, S.O.; Fujii, N.; Kira, J.I.; Iwaki, T. Mitochondrial dysfunction and altered ribostasis in hippocampal neurons with cytoplasmic inclusions of multiple system atrophy. Neuropathology 2018, 38, 361-371. [CrossRef] [PubMed]

122. Jellinger, K.A.; Korczyn, A.D. Are dementia with Lewy bodies and Parkinson's disease dementia the same disease? BMC Med. 2018, 16, 34. [CrossRef] [PubMed] 
123. McKeith, I.G.; Boeve, B.F.; Dickson, D.W.; Halliday, G.; Taylor, J.P.; Weintraub, D.; Aarsland, D.; Galvin, J.; Attems, J.; Ballard, C.G.; et al. Diagnosis and management of dementia with Lewy bodies: Fourth consensus report of the DLB Consortium. Neurology 2017, 89, 88-100. [CrossRef] [PubMed]

124. Zhang, W.; Zhang, Q.; Yang, Q.; Liu, P.; Sun, T.; Xu, Y.; Qian, X.; Qiu, W.; Ma, C. Contribution of Alzheimer's disease neuropathologic change to the cognitive dysfunction in human brains with Lewy body-related pathology. Neurobiol. Aging 2020, 91, 56-65. [CrossRef]

125. Homma, T.; Mochizuki, Y.; Tobisawa, S.; Komori, T.; Takahashi, K. Tufted astrocyte-like glia in two autopsy cases of multiple system atrophy: Is it a concomitant neurodegenerative disorder with multiple system atrophy and progressive supranuclear palsy? Neuropathology 2021, 42, 74-81. [CrossRef]

126. Eschlböck, S.; Delazer, M.; Krismer, F.; Bodner, T.; Fanciulli, A.; Heim, B.; Heras Garvin, A.; Kaindlstorfer, C.; Karner, E.; Mair, K.; et al. Cognition in multiple system atrophy: A single-center cohort study. Ann. Clin. Transl. Neurol. 2020, 7, 219-228. [CrossRef]

127. Caso, F.; Canu, E.; Lukic, M.J.; Petrovic, I.N.; Fontana, A.; Nikolic, I.; Kostic, V.S.; Filippi, M.; Agosta, F. Cognitive impairment and structural brain damage in multiple system atrophy-parkinsonian variant. J. Neurol. 2020, 267, 87-94. [CrossRef]

128. Gatto, E.; Demey, I.; Sanguinetti, A.; Parisi, V.; Etcheverry, J.L.; Rojas, G.; Wenning, G.K. Cognition in a multiple system atrophy series of cases from Argentina. Arq. Neuropsiquiatr. 2014, 72, 773-776. [CrossRef]

129. Kawai, Y.; Suenaga, M.; Takeda, A.; Ito, M.; Watanabe, H.; Tanaka, F.; Kato, K.; Fukatsu, H.; Naganawa, S.; Kato, T.; et al. Cognitive impairments in multiple system atrophy: MSA-C vs MSA-P. Neurology 2008, 70, 1390-1396. [CrossRef]

130. Yang, H.; Luo, X.; Yu, H.; Guo, M.; Cao, C.; Li, Y.; Fan, G. Altered resting-state voxel-level whole-brain functional connectivity in multiple system atrophy patients with cognitive impairment. Clin. Neurophysiol. 2020, 131, 54-62. [CrossRef]

131. Barcelos, L.B.; Saad, F.; Giacominelli, C.; Saba, R.A.; de Carvalho Aguiar, P.M.; Silva, S.M.A.; Borges, V.; Bertolucci, P.H.F.; Ferraz, H.B Neuropsychological and clinical heterogeneity of cognitive impairment in patients with multiple system atrophy. Clin. Neurol. Neurosurg. 2018, 164, 121-126. [CrossRef] [PubMed]

132. Miki, Y.; Ling, H.; Foti, S.C.; Hansen, D.; Strand, K.M.; Asi, Y.T.; Jaunmuktane, Z.; Lees, A.J.; Warner, T.T.; Quinn, N.; et al Hippocampal a-synuclein pathology correlates with memory impairment in multiple system atrophy (abstr.). Neuropathol. Appl. Neurobiol. 2020, 46, 22

133. Hata, Y.; Ma, N.; Yoneda, M.; Morimoto, S.; Okano, H.; Murayama, S.; Kawanishi, S.; Kuzuhara, S.; Kokubo, Y. Nitrative stress and tau accumulation in amyotrophic lateral sclerosis/parkinsonism-dementia complex (ALS/PDC) in the Kii peninsula, Japan. Front. Neurosci. 2018, 11, 751. [CrossRef] [PubMed]

134. Asi, Y.T.; Ling, H.; Ahmed, Z.; Lees, A.J.; Revesz, T.; Holton, J.L. Neuropathological features of multiple system atrophy with cognitive impairment. Mov. Disord. 2014, 29, 884-888. [CrossRef]

135. Terni, B.; Rey, M.J.; Boluda, S.; Torrejon-Escribano, B.; Sabate, M.P.; Calopa, M.; van Leeuwen, F.W.; Ferrer, I. Mutant ubiquitin and p62 immunoreactivity in cases of combined multiple system atrophy and Alzheimer's disease. Acta Neuropathol. 2007, 113, 403-416. [CrossRef]

136. Lin, C.W.; Tseng, C.Y.; Lo, C.P.; Tu, M.C. A case of multiple system atrophy with preexisting Alzheimer's disease and predating the hot cross bun sign. Acta Neurol. Taiwan 2016, 25, 152-159.

137. Nagaishi, M.; Yokoo, H.; Nakazato, Y. Tau-positive glial cytoplasmic granules in multiple system atrophy. Neuropathology 2011, 31, 299-305. [CrossRef]

138. Homma, T.; Mochizuki, Y.; Tobisawa, S.; Komori, T.; Isozaki, E. Cerebral white matter tau-positive granular glial pathology as a characteristic pathological feature in long survivors of multiple system atrophy. J. Neurol. Sci. 2020, 416, 117010. [CrossRef]

139. Neddens, J.; Temmel, M.; Flunkert, S.; Kerschbaumer, B.; Hoeller, C.; Loeffler, T.; Niederkofler, V.; Daum, G.; Attems, J.; Hutter-Paier, B. Phosphorylation of different tau sites during progression of Alzheimer's disease. Acta Neuropathol. Commun. 2018, 6, 52. [CrossRef]

140. Ashton, N.J.; Pascoal, T.A.; Karikari, T.K.; Benedet, A.L.; Lantero-Rodriguez, J.; Brinkmalm, G.; Snellman, A.; Schöll, M.; Troakes, C.; Hye, A.; et al. Plasma p-tau231: A new biomarker for incipient Alzheimer's disease pathology. Acta Neuropathol. 2021, 141, 709-724. [CrossRef]

141. Takanashi, M.; Ohta, S.; Matsuoka, S.; Mori, H.; Mizuno, Y. Mixed multiple system atrophy and progressive supranuclear palsy: A clinical and pathological report of one case. Acta Neuropathol. 2002, 103, 82-87. [CrossRef] [PubMed]

142. Uchikado, H.; DelleDonne, A.; Uitti, R.; Dickson, D.W. Coexistence of PSP and MSA: A case report and review of the literature. Acta Neuropathol. 2006, 111, 186-192. [CrossRef] [PubMed]

143. Arai, Y.; Yamazaki, M.; Mori, O.; Muramatsu, H.; Asano, G.; Katayama, Y. Alpha-synuclein-positive structures in cases with sporadic Alzheimer's disease: Morphology and its relationship to tau aggregation. Brain Res. 2001, 888, 287-296. [CrossRef]

144. Lei, P.; Ayton, S.; Finkelstein, D.I.; Adlard, P.A.; Masters, C.L.; Bush, A.I. Tau protein: Relevance to Parkinson's disease. Int. J. Biochem. Cell Biol. 2010, 42, 1775-1778. [CrossRef] [PubMed]

145. Shao, C.Y.; Crary, J.F.; Rao, C.; Sacktor, T.C.; Mirra, S.S. Atypical protein kinase C in neurodegenerative disease II: PKCiota/lambda in tauopathies and alpha-synucleinopathies. J. Neuropathol. Exp. Neurol. 2006, 65, 327-335. [CrossRef]

146. Jellinger, K.A. Interaction between alpha-synuclein and other proteins in neurodegenerative disorders. ScientificWorldJournal 2011, 11, 1893-1907. [CrossRef]

147. Guo, J.L.; Covell, D.J.; Daniels, J.P.; Iba, M.; Stieber, A.; Zhang, B.; Riddle, D.M.; Kwong, L.K.; Xu, Y.; Trojanowski, J.Q.; et al. Distinct alpha-synuclein strains differentially promote tau inclusions in neurons. Cell 2013, 154, 103-117. [CrossRef] 
148. Boesch, S.M.; Wenning, G.K.; Ransmayr, G.; Poewe, W. Dystonia in multiple system atrophy. J. Neurol. Neurosurg. Psychiatry 2002, 72, 300-303. [CrossRef]

149. Perlmutter, J.S.; Stambuk, M.K.; Markham, J.; Black, K.J.; McGee-Minnich, L.; Jankovic, J.; Moerlein, S.M. Decreased [18F]spiperone binding in putamen in idiopathic focal dystonia. J. Neurosci. 1997, 17, 843-850. [CrossRef]

150. Levy, L.M.; Hallett, M. Impaired brain GABA in focal dystonia. Ann. Neurol. 2002, 51, 93-101. [CrossRef]

151. Berardelli, A.; Rothwell, J.C.; Hallett, M.; Thompson, P.D.; Manfredi, M.; Marsden, C.D. The pathophysiology of primary dystonia. Brain 1998, 121, 1195-1212. [CrossRef]

152. Jellinger, K.A. Neuropathological findings in multiple system atrophy with dystonia. J. Neurol. Neurosurg. Psychiatry 2002, 73 , 460-461. [CrossRef]

153. Kofler, M.; Wenning, G.K.; Poewe, W.; Jellinger, K.; Maier, H. Cortical and brain stem hyperexcitability in a pathologically confirmed case of multiple system atrophy. Mov. Disord. 2000, 15, 362-363. [CrossRef]

154. Okuma, Y.; Fujishima, K.; Miwa, H.; Mori, H.; Mizuno, Y. Myoclonic tremulous movements in multiple system atrophy are a form of cortical myoclonus. Mov. Disord. 2005, 20, 451-456. [CrossRef] [PubMed]

155. Kaindlstorfer, C.; Granata, R.; Wenning, G.K. Tremor in multiple system atrophy-A review. Tremor Other Hyperkinet. Mov. 2013, 3, tre-03-165-4252-4251. [CrossRef]

156. Hwang, J.; Bank, A.M.; Mortazavi, F.; Oakley, D.H.; Frosch, M.P.; Schmahmann, J.D. Spinal cord alpha-synuclein deposition associated with myoclonus in patients with MSA-C. Neurology 2019, 93, 302-309. [CrossRef] [PubMed]

157. Coon, E.A.; Rocca, W.; Melson, C.S.; Ahlskog, J.E.; Matsumoto, J.Y.; Low, P.A.; Singer, W. Conjugal multiple system atrophy: Chance, shared risk factors, or evidence of transmissibility? Parkinsonism Relat. Disord. 2019, 67, 10-13. [CrossRef]

158. Nan, H.; Natori, T.; Ichinose, Y.; Koh, K.; Kobayashi, F.; Shindo, K.; Hashiyada, M.; Adachi, N.; Yamagata, Z.; Takiyama, Y. Conjugal cerebellar type of multiple system atrophy: Person-to-person transmission? Parkinsonism Relat. Disord. 2019, 69, 68-70. [CrossRef]

159. Mitterer, W.; Lanser, L.; Fodor, M.; Weiss, J.; Scholz, S.W.; Wenning, G.K. Conjugal multiple system atrophy: Rethinking numbers of probability. Parkinsonism Relat. Disord. 2020, 77, 176-177. [CrossRef]

160. Lemos, M.; Wenning, G.K.; Stefanova, N. Current experimental disease-modifying therapeutics for multiple system atrophy. J. Neural Transm. 2021, 128, 1529-1543. [CrossRef]

161. Coon, E.A.; Ahlskog, J.E. My treatment approach to multiple system atrophy. Mayo Clin. Proc. 2021, 96, 708-719. [CrossRef] [PubMed]

162. Jellinger, K.A. Potential clinical utility of multiple system atrophy biomarkers. Expert Rev. Neurother. 2017, 17, 1189-1208. [CrossRef] [PubMed]

163. Meissner, W.G.; Fernagut, P.O.; Dehay, B.; Peran, P.; Traon, A.P.; Foubert-Samier, A.; Lopez Cuina, M.; Bezard, E.; Tison, F.; Rascol, O. Multiple system atrophy: Recent developments and future perspectives. Mov. Disord. 2019, 34, 1629-1642. [CrossRef] [PubMed]

164. Xie, D.; Feng, L.; Huang, H.; Zhao, Q.; Ning, P.; Shen, Q.; Lu, H.; Xu, F.; Xu, Y. Cerebrospinal Fluid Biomarkers in Multiple System Atrophy Relative to Parkinson's Disease: A Meta-Analysis. Behav. Neurol. 2021, 2021, 5559383. [CrossRef]

165. Cong, S.; Xiang, C.; Wang, H. Diagnostic utility of fluid biomarkers in multiple system atrophy: A systematic review and meta-analysis. J. Neurol. 2021, 268, 2703-2712. [CrossRef]

166. Kim, J.S.; Yang, J.J.; Lee, D.K.; Lee, J.M.; Youn, J.; Cho, J.W. Cognitive impairment and its structural correlates in the parkinsonian subtype of multiple system atrophy. Neurodegener. Dis. 2015, 15, 294-300. [CrossRef]

167. Miki, Y.; Tsushima, E.; Foti, S.C.; Strand, K.M.; Asi, Y.T.; Yamamoto, A.K.; Bettencourt, C.; Oliveira, M.C.B.; De Pablo-FernÃ jndez, E.; Jaunmuktane, Z.; et al. Identification of multiple system atrophy mimicking Parkinson's disease or progressive supranuclear palsy. Brain 2021, 144, 1138-1151. [CrossRef]

168. Palma, J.A.; Norcliffe-Kaufmann, L.; Kaufmann, H. Diagnosis of multiple system atrophy. Auton. Neurosci. 2018, 211, 15-25. [CrossRef]

169. Marsili, L.; Giannini, G.; Cortelli, P.; Colosimo, C. Early recognition and diagnosis of multiple system atrophy: Best practice and emerging concepts. Expert Rev. Neurother. 2021, 21, 993-1004. [CrossRef]

170. Xia, C.; Postuma, R.B. Diagnosing multiple system atrophy at the prodromal stage. Clin. Auton. Res. 2020, 30, 197-205. [CrossRef] 